Creative Commons User Licence: CC BY-NC-ND

Abstracted by: EBSCOhost, Electronic Journals Service (EJS),

Google Scholar, Directory of Open Access Journals (DOAJ),

Journal Seek, Scientific Commons, and

Food and Agricultural Organization (FAO)
Journal of Agricultural Extension

Vol.19 (1) June, 2015

ISSN 24086851

http://journal.aesonnigeria.org

http://www.ajol.info/index.php/jae

http://dx.doi.org/10.4314.jae.v19i1.7

\title{
Assessment of Food Security Situation of Tiv Farming households in Nigeria
}

\section{Dooshima P Ivanda ${ }^{1}$, Edwin M Igbokwe ${ }^{2}$ Olaolu Michael Olatunji ${ }^{2}$}

${ }^{\mathbf{1}}$ Department of Home Science and Management, University of Agriculture, Makurdi, Benue state, Nigeria

${ }^{2}$ Department of Agricultural Extension, University Nigeria Nsukka, Enugu state

\section{Abstract}

The study assessed the food security situation and living conditions of Tiv farming households. Respondents were drawn from farming households in Benue, Taraba and Nasarawa States. Data was collected from 315 heads of households using interview schedule, and the data were analysed using means and food security index. The study found that enhanced ICT use $(M=2.47)$ and increased competition $(M=2.40)$ were perceived conditions that were found to be attributed to their agricultural operations. The analysis of food security situation shows that majority (64.1\%) of these households were food secured. This could be because those strategies for ensuring food security is working for majority of the families. Also on the strategies put in place to ensure households' food security were the use of high yielding crop varieties $(M=1.60)$, mixed cropping $(M=1.53)$ and use of early maturing crop varieties. It was recommended that governments in these states should support various extension agencies by funding these agencies to be involved in the dissemination of these technologies that enhance the food security of the farmers.

Key words: Food security; Tiv farming families; strategies

\section{Introduction}

Food security has become an issue of global concern in the recent time. Nigeria, with her huge endowed natural and human resources is not spared. Nigerian environment is characterized by fair to good soils but poor and unreliable rainfall and low quantity as the case in arid and semiarid regions (Oriola, 2009). Endowed with about 74 million hectares land for arable crop production and additional 2.5million hectares of Irrigable land yet the country has not been able to take comparative advantage of the climatic condition, the large expanse of land and ever increasing teaming population to make her sufficient in food production. This is despite the fact 
Creative Commons User Licence: CC BY-NC-ND

Abstracted by: EBSCOhost, Electronic Journals Service (EJS),

Google Scholar, Directory of Open Access Journals (DOAJ),

Journal Seek, Scientific Commons, and

Food and Agricultural Organization (FAO)
Journal of Agricultural Extension

Vol.19 (1) June, 2015

ISSN 24086851

http://journal.aesonnigeria.org

http://www.ajol.info/index.php/jae

that variety of crops thrive well with maximum yield in different ecological zones of the country. Nigerian food crisis is a product of colonial disorientation that has led to neglect of the peasant agriculture and food crops sub-sector as well as over reliance on cash crops production and the oil sector (Attah, 2012).

In the recent time, there have been a lot of concerns expressed over the looming danger of food crisis in many nations, including Nigeria. The Food and Agricultural Organization, among others have been persistent in expressing these concerns for the global food crisis over the years. According to Food and Agriculture Organization, food security obtains when all people, at all times, have physical and economic access to sufficient, safe and nutritious food to meet their dietary needs and food preferences for an active and healthy life (FAO, 1996). The main goal of food security therefore, is for individuals to be able to obtain adequate food needed at all times, and to be able to utilise the food to meet the body's needs. Food security is multifaceted. The World Bank (2001) identified three pillars underpinning food security. These are food availability, food accessibility, and food utilization. This means that a nation whose food production level is unable to satisfy these three criteria is said to be food insecure. Supporting this assertion, Maxwell (in Nana- Sinkam 1995) stated that a country and its people are food secured when their food system operates in such a way as to remove the fear that there will not be enough to eat. He further stressed that food security requires that the poor and vulnerable have secure access to the food they want. The World Food Summit plan of Action of 1996( according to Attah, (2012) states that food insecurity occurs when;

- People experience a large reduction in their sources of food and are unable to make up the difference through new strategies.

- The prevalence of malnutrition is abnormally high for most time of the year, and this cannot be accounted for by either health or care factors.

- A large proportion of the population or group is using marginal or unsuitable strategies, and

- People are using "coping" strategies that are damaging to their livelihoods in the longer term or incur some other unacceptable cost, such as acting illegally or immorally. 
Creative Commons User Licence: CC BY-NC-ND

Abstracted by: EBSCOhost, Electronic Journals Service (EJS),

Google Scholar, Directory of Open Access Journals (DOAJ),

Journal Seek, Scientific Commons, and

Food and Agricultural Organization (FAO)
Journal of Agricultural Extension

Vol.19 (1) June, 2015

ISSN 24086851

http://journal.aesonnigeria.org

http://www.ajol.info/index.php/jae

According to Attah (2012), Nigeria's situation on food security is highly precarious and pernicious as a significant percentage of the Nigerian population is left with only the bilious taste of poverty. Haruna, a member of the House of Representatives in an emotion laden speech in 2005 said, "People are dying and the hunger is simply unbearable. We need to tell ourselves the truth; there is hunger in the Land. Our people go to bed with empty stomachs (TELL: August 22, 2005:23 in Attah, 2012). This lamentation persists till today in Nigeria, given these criteria presented by the World Food Summit plan of Action in 1996 (in Attah, 2012).

However, technological development has given the opportunity to tap the two important natural resources (water and soil) for cultivating the land all year round through irrigation (Oriola, 2009). Nigeria still has the potentials to be food-secure if the following strategies are adopted and implemented: rural development, provision of easy access to basic farm inputs, adequate budgetary allocations to agriculture particularly to the food crop sub-sector, enunciation of appropriate policies for food crop sub-sector, political stability, reduction in rural poverty, and peasant farmers' education (Attah, 2012).

In order to deal with the problems of food insecurity and high incidence of poverty among the rural poor in Nigeria, it is very imperative that agricultural productivity should be rejuvenated. It has been empirically established that low productivity in agriculture is the cause of high incidence of food insecurity and poverty in Nigeria (World bank, 1996). This is because agriculture is the mainstay of Nigeria's economy, contributing about 42\% to total GDP and employing about 77\% of the working population (Olaolu, Akinnagbe and Agber, 2013). It is therefore obvious that any policy measure aimed at alleviating poverty must take agriculture and rural development into consideration. The Federal Office of Statistic/World Bank (2001) in Adeolu and Taiwo (2004), analyzed the poverty trend in Nigeria and noted that poor families are in higher proportion in farming households that are mainly in the rural area. Therefore, it is very important to raise food production, create employment, and improve the institutional and policy framework for agriculture, as well as to rehabilitate and expand physical and social infrastructure in rural areas; all of which require increased and sustained investment and support for agriculture (Franz et al, 2004 in Olaolu et al 2013). 
Creative Commons User Licence: CC BY-NC-ND

Abstracted by: EBSCOhost, Electronic Journals Service (EJS),

Google Scholar, Directory of Open Access Journals (DOAJ),

Journal Seek, Scientific Commons, and

Food and Agricultural Organization (FAO)
Journal of Agricultural Extension

Vol.19 (1) June, 2015

ISSN 24086851

http://journal.aesonnigeria.org

http://www.ajol.info/index.php/iae

A trend analysis of agricultural performance of Benue state (where the Tiv people are the most dominant people group) from 1986 (when concrete data can be seen) shows that there was steady increase in crop production from 1986 - 2007 with total crop production between 2001 2007 standing at 7652.99 tonnes (Ivande, 2014). On individual crop analysis, maize and sorghum showed a decrease output from 1996-2000 but had resumed upward trend from 2001 - 2007 while millet and cassava have decreased output in the same period. Others (rice, yam, groundnuts, cowpea and soybean) had maintained a steady increase in output indicating possible utilization of the innovations, technologies, skills (Ivande, 2014).

Based on the above trends, could these changes in agricultural production have resulted in food self-sufficiency as well as coping with vulnerability and risk in food and nutrition access among the Tiv farming households? From this the questions that readily come to mind are: what are the living conditions of the Tiv farming families attributable to their agricultural activities? What is the food security situation of these Tiv farming households? And Are there measures put in place to ensure food security of their households? These questions among others have necessitated the need for an assessment of the food security situation of the Tiv farming households.

\section{Purpose of the study}

The broad purpose of this study was to assess the Food security situation of Tiv farming households, specifically the study sought to:

1. ascertain the living conditions of Tiv farming households attributable to changes in agricultural activities;

2. analyse Tiv farming families' food security status and;

3. identify strategies put in place to ensure farming families' food security.

\section{Methodology}

The study was carried out among the Tiv in Benue, Nasarawa, and Taraba States, Nigeria. The population comprises all the farm families in Benue, Taraba and Nasarawa States. A multistage sampling procedure was employed to select farm families. Two agricultural zones 
Creative Commons User Licence: CC BY-NC-ND

Abstracted by: EBSCOhost, Electronic Journals Service (EJS),

Google Scholar, Directory of Open Access Journals (DOAJ),

Journal Seek, Scientific Commons, and

Food and Agricultural Organization (FAO)
Journal of Agricultural Extension

Vol.19 (1) June, 2015

ISSN 24086851

http://journal.aesonnigeria.org

http://www.ajol.info/index.php/jae

predominantly populated by the Tiv, namely, zones A and B Benue and one each in Nasarawa and Taraba where Tiv people are predominantly populated were purposively selected. Three blocks from zone A, two from B in Benue State and one each from southern zones of Nasarawa and Taraba were purposively selected giving a total of seven blocks, this is because of the dominance of Tiv farmers in these locations. Three cells/villages were purposively selected from each block giving a total of 21 cells/villages. From the list of farm families from each of the cells/villages, 15 farm households giving a sample size of 315 farm households.

Data were collected through the use of structured interview schedule and FGD. The interview schedule was divided into different sections on the basis of the objectives. Content and face validity was done by lecturers in the Department of Agricultural Extension, University of Nigeria, Nsukka. To ascertain the living condition that could be attributed to agricultural operation as perceived by the households, respondents were asked to indicate the extent they attributed socioeconomic conditions of the people to agricultural operations on a 4 point rating scale; to a very large extent (TVLE=3), to a large extent $(\mathrm{TLE}=2)$, to some extent $(\mathrm{TSE}=1)$ and to no extent $(\mathrm{TNE}=0)$. A decision mean of 1.5 was derived. Any condition with a mean value equal or greater than 1.5 was regarded as attributable, while any condition with mean value below 1.5 was regarded as not attributable to agricultural operation. The possible socio-economic conditions include: improved possession of household items, reduced mortality rate, improved nutrition among others.

To ascertain the food security status, food security index was measured by per-capital food expenditure of households examined (both cash and farm produce consumptions) in their naira value per house. For food security index, the households were classified into food secure and food insecure households using food security index, as used by Omonona, Bolarin, Agoi, \& Adetokunbo,(2007), the food security index used, it is given as:

$F i=\frac{\text { Per capita food expenditure on } i \text { th household }}{\frac{2}{3} \text { mean per capita food expenditure in all household }}$

Where $\mathrm{Fi}=$ food security index 
Creative Commons User Licence: CC BY-NC-ND

Abstracted by: EBSCOhost, Electronic Journals Service (EJS),

Google Scholar, Directory of Open Access Journals (DOAJ),

Journal Seek, Scientific Commons, and

Food and Agricultural Organization (FAO)
Journal of Agricultural Extension

Vol.19 (1) June, 2015

ISSN 24086851

http://journal.aesonnigeria.org

http://www.ajol.info/index.php/jae

When Fi $\geq 1=$ food secure ith household

$\mathrm{Fi} \leq 1=$ food insecure ith household.

To identify strategies put in place to ensure household food security, a list of strategies were provided for the respondents against which they were required to indicate the frequency of their practicing these strategies. Their frequency of use was rated on a scale of often (2), seldom (1) and never (0). A decision mean of 1.5 was derived. Any strategy with a mean value equal or greater than 1.5 was regarded as a strategy put in place to ensure food security, while any strategy with mean value below 1.5 was regarded as not a strategy. Data were analyzed with the use of frequencies, percentage, mean statistic and food security index. 
Creative Commons User Licence: CC BY-NC-ND

Abstracted by: EBSCOhost, Electronic Journals Service (EJS),

Google Scholar, Directory of Open Access Journals (DOAJ),

Journal Seek, Scientific Commons, and

Food and Agricultural Organization (FAO)
Journal of Agricultural Extension

Vol.19 (1) June, 2015

ISSN 24086851

http://journal.aesonnigeria.org

http://www.ajol.info/index.php/jae

\section{Results and Discussions}

\section{Socio-Economic Conditions Attributed to changes in Agriculture among the Tiv}

A number of conditions were attributed to changes in agriculture among which include: enhanced ICT use $(M=2.47)$, increased competition $(M=2.40)$ and long distance trade in farm produce $(\mathrm{M}=2.21)$. Others included: rivalry $(\mathrm{M}=1.81)$, increased literacy $(\mathrm{M}=1.80)$, increased enrolment of children in schools $(\mathrm{M}=1.58)$, improved clothing needs of household $(\mathrm{M}=1.54)$, improved health status $(\mathrm{M}=1.54)$ and improved nutrition $(\mathrm{M}=1.50)$ (Table 1). The results shows the standard deviations that ranged from between 0.69 and 0.97 , this indicates a low standard deviation values which implies that the opinions of the respondents on these conditions are close to the respective means scores, meaning that the mean scores are similar opinions among most respondents.

This result shows that changes in agricultural operation has eventually led to improvement of the living level of the farmers as increased enrollment of children in school, improved health status and improved clothing needs of households are critical to living standards. This improvement in the living standard means that changes in agricultural operation has improved their economic status.

In line with this finding Rivera (2003) affirms that improving the living standard of smallholder farmers means confronting the problems that the farmers and their families face in their daily struggle for survival through improvements in agriculture and resultant income generation. Macionis and Plummer (2005) also affirms that agriculture transforms a society through the use of new or improved technological innovations of a particular period. Specifically they observed that the discovery of the technology of molding metals propelled the transition from horticulture to agriculture and for the first time put men into dominant position in the production of food at the time.

Also due to improved technology leading to increased farm sizes and consequent increased yields with possible plenty surpluses for sale, needing markets where good prices for produce was possible, long distance trade became a characteristic of the post colonial Tiv. 
Creative Commons User Licence: CC BY-NC-ND

Abstracted by: EBSCOhost, Electronic Journals Service (EJS),

Google Scholar, Directory of Open Access Journals (DOAJ),

Journal Seek, Scientific Commons, and

Food and Agricultural Organization (FAO)
Journal of Agricultural Extension

Vol.19 (1) June, 2015

ISSN 24086851

http://journal.aesonnigeria.org

http://www.ajol.info/index.php/jae 
Creative Commons User Licence: CC BY-NC-ND

Abstracted by: EBSCOhost, Electronic Journals Service (EJS),

Google Scholar, Directory of Open Access Journals (DOAJ),

Journal Seek, Scientific Commons, and

Food and Agricultural Organization (FAO)
Journal of Agricultural Extension

Vol.19 (1) June, 2015

ISSN 24086851

http://journal.aesonnigeria.org

http://www.ajol.info/index.php/jae

Table 1: Mean distribution of respondents on living conditions attributable to changes in agricultural operation

\begin{tabular}{lcc}
\hline Conditions & Mean & Std. Deviation \\
\hline Improved clothing needs of households & $1.54^{*}$ & 0.692 \\
Improved possession of household items & 1.39 & 0.721 \\
Improved basic rural infrastructure & 1.33 & 0.757 \\
Reduced mortality rate & 1.20 & 0.972 \\
Improved nutrition & 1.50 & 0.861 \\
Improved health facilities & 1.45 & 0.714 \\
Increased literacy & $1.80^{*}$ & 0.834 \\
Enhanced ICT use & $2.47 *$ & 0.715 \\
Increased competition & $2.40^{*}$ & 0.717 \\
Long distance trade in farm produce & $2.21^{*}$ & 0.793 \\
Increased rivalry & 1.81 & 0.893 \\
Increased number of children & 1.15 & 0.780 \\
Increased enrolment of children in schools & $1.58^{*}$ & 0.716 \\
Improved health status & $1.54^{*}$ & 0.673 \\
Multiple wives & 0.90 & 0.806 \\
Possession of more household items and gadgets & 1.31 & 0.825 \\
\hline
\end{tabular}

*living conditions attributable to their agricultural activities

\section{Food security assessment of the Tiv farming households across states}

The percentage distribution in figure 1 are representations of the proportion of food secured and food insecured household among the Tiv farming household by states. The Figure shows that even though in all the states majority of the households were food secured, Taraba State has the highest 
Creative Commons User Licence: CC BY-NC-ND

Abstracted by: EBSCOhost, Electronic Journals Service (EJS),

Google Scholar, Directory of Open Access Journals (DOAJ),

Journal Seek, Scientific Commons, and

Food and Agricultural Organization (FAO)
Journal of Agricultural Extension

Vol.19 (1) June, 2015

ISSN 24086851

http://journal.aesonnigeria.org

http://www.ajol.info/index.php/iae

(82.2\%) proportion of households who are food secured, while the next state is Nassarawa State where $75.6 \%$ of the households were food secure while barely above half $(58.2 \%)$ of the households in Benue state were food secured. This result shows that the food security situation is better in Taraba State while Benue still seeks more improvement in the food security situation among the Tiv people.

The overall result shows that majority $(64.1 \%)$ of the households were food secured, while the remaining $35.9 \%$ of the household were not. The situation of food security among the Tiv farming household shows that more than half of the households were able to obtain adequate food needed at all times, and to be able to utilise the food to meet the body's needs. This implies that the trend of changes among the Tiv in agriculture has also resulted in a situation of enhanced food availability, accessibility and utilisation among the farming household. This result agrees with the findings of Olaolu et al (2013) where majority (91\%) of the rice farmers who benefited from the national Fadama development project in Kogi state were food secured while only a few were not.

Despite the fact that majority of these households are food secured, the farming households who were not food secured were more than one quarter of the respondents, this is an indication that more still needs to be done to improve the food security situation among the Tiv farming households. 
Creative Commons User Licence: CC BY-NC-ND

Abstracted by: EBSCOhost, Electronic Journals Service (EJS),

Google Scholar, Directory of Open Access Journals (DOAJ),

Journal Seek, Scientific Commons, and

Food and Agricultural Organization (FAO)
Journal of Agricultural Extension

Vol.19 (1) June, 2015

ISSN 24086851

http://journal.aesonnigeria.org

http://www.ajol.info/index.php/jae

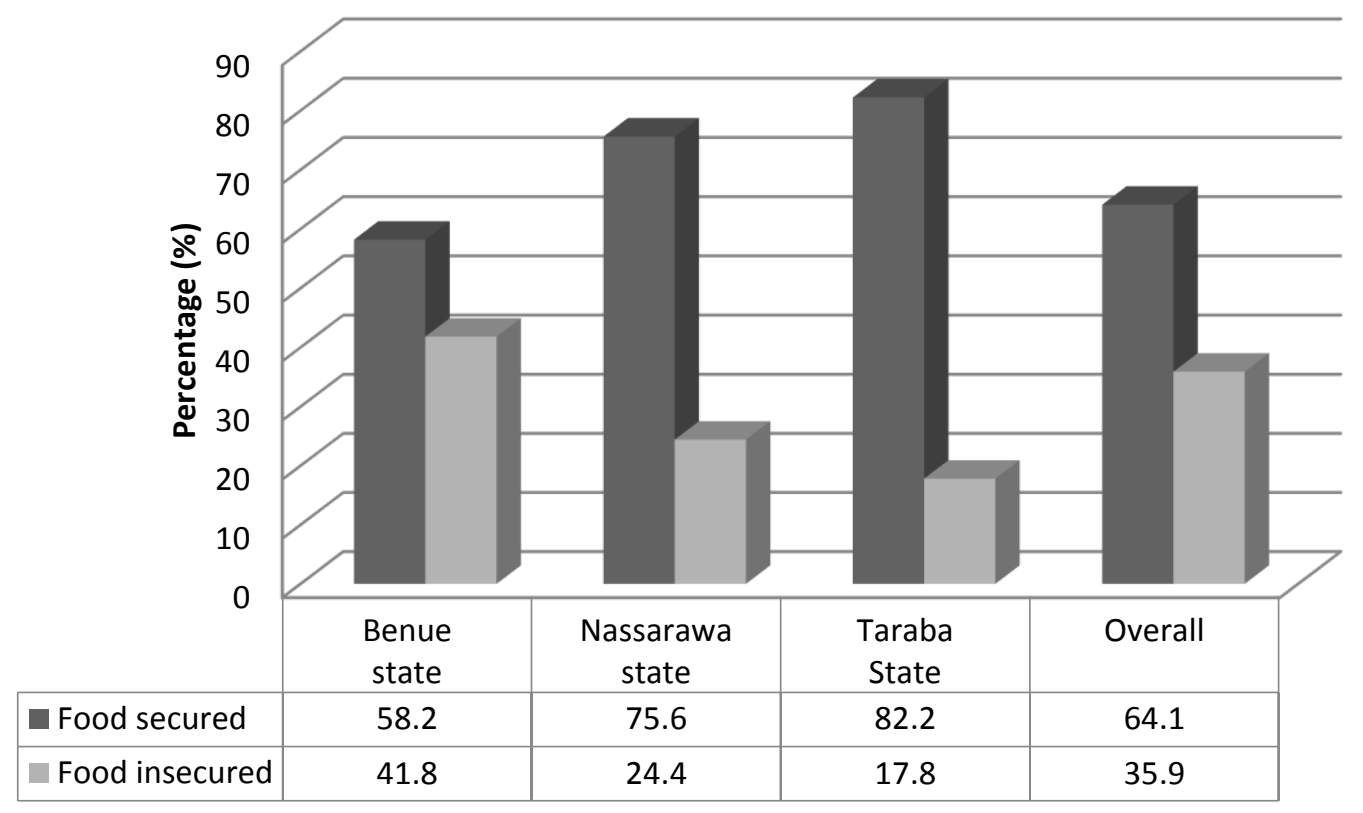

Figure 1:Percentage distribution of respondents according to their food security status acroos states where the Tiv people are

\section{Strategies put in place to ensure food security among the Tiv farming households}

A number of strategies were identified to have been put in place to ensure food security among which include: mixed cropping $(M=1.53)$, use of early maturing crop varieties $(M=1.50)$, crop diversification ( $\mathrm{M}=1.50)$ and the use of high yielding crop varieties $(\mathrm{M}=1.60)$ (Table 2). The result also shows that there are still several other strategies not in place to ensure food security of the households.

The results show that there are a few strategies put in plaace to ensure food security of these households. The result also indicated that all the strategies put in place are strategies that will increase the production of these farming households. This shows that these household are only limited to strategies that are focused on enhancing their farming production. But fail to ensure that these farm produce are well stored to enable high availability across the year which one pillar of the food security.

According to USAID (1992), food security will be ensured when there is access by all people at all times to enough food for an active, healthy life. All people at all times have both 
Creative Commons User Licence: CC BY-NC-ND

Abstracted by: EBSCOhost, Electronic Journals Service (EJS),

Google Scholar, Directory of Open Access Journals (DOAJ),

Journal Seek, Scientific Commons, and

Food and Agricultural Organization (FAO)
Journal of Agricultural Extension

Vol.19 (1) June, 2015

ISSN 24086851

http://journal.aesonnigeria.org http://www.ajol.info/index.php/jae

physical and economic access to the basic food they need. Access by all people at all times to sufficient food and nutrition for a healthy and productive life. When all people at all times have access to sufficient food to meet their dietary needs for a productive and healthy life".

Obamiro, Doppler and Kormawa, (2003) examined the pillars of food security in rural areas of Nigeria. They found out that food security is a multifaceted concept, which cannot be treated in isolation from other indexes of living standards and suggested that efforts geared towards achieving food security in Nigeria should also address other areas of human and infrastructure development.

These other findings show that approaching food security from only one aspect will not adequately ensure a proper food security of the households. Also there is an increased need for ensuring better ways of ensuring food security by exploring other approaches. 
Creative Commons User Licence: CC BY-NC-ND

Abstracted by: EBSCOhost, Electronic Journals Service (EJS),

Google Scholar, Directory of Open Access Journals (DOAJ),

Journal Seek, Scientific Commons, and

Food and Agricultural Organization (FAO)
Journal of Agricultural Extension

Vol.19 (1) June, 2015

ISSN 24086851

http://journal.aesonnigeria.org

http://www.ajol.info/index.php/jae

Table 2: Mean distribution of respondents on strategies put in place to ensure food security of the Tiv farming households

\section{Strategies}

Relay cropping of yam and other early maturing crops

Crop diversification

Mixed cropping

Mixed farming

Fadama farming

Occupational diversification

Farm diversification

Use of long shelf live storage facility

Planting of heat resistant crops

Processing of root and tubers into longer shelf life forms

Processing and treatment of grains using chemicals for longer shelf life

Processing of legumes with insect powders for longer shelf life

Use of early maturing crop varieties

Use of hazard resistant crop varieties

Use of high yielding crop varieties

Storage practices

0.97

0.584

$1.53^{*}$

0.612

0.46

0.629

0.69

0.735

1.15

0.610

1.17

0.620

1.22

0.579

1.14

0.660

1.18

0.639

1.27

0.629

$1.50 *$

0.543

0.94

0.735

$1.60 *$

0.509

Restriction of sales of food crops 
Creative Commons User Licence: CC BY-NC-ND

Abstracted by: EBSCOhost, Electronic Journals Service (EJS),

Google Scholar, Directory of Open Access Journals (DOAJ),

Journal Seek, Scientific Commons, and

Food and Agricultural Organization (FAO)

*strategies in place to ensure food security
Journal of Agricultural Extension

Vol.19 (1) June, 2015

ISSN 24086851

http://journal.aesonnigeria.org

http://www.ajol.info/index.php/jae 
Creative Commons User Licence: CC BY-NC-ND

Abstracted by: EBSCOhost, Electronic Journals Service (EJS),

Google Scholar, Directory of Open Access Journals (DOAJ),

Journal Seek, Scientific Commons, and

Food and Agricultural Organization (FAO)
Journal of Agricultural Extension

Vol.19 (1) June, 2015

ISSN 24086851

http://journal.aesonnigeria.org

http://www.ajol.info/index.php/jae

\section{Conclusion}

There is high incidence of food security among the majority of the Tiv households whose household food expenditure exceeds the $2 / 3^{\text {rd }}$ of the mean of their household food expenditure. There is also improvements in clothing needs of household, health status and nutrition of the households. For better food security plan for Tiv households there is a need to better food preservation for constant accessibility.

\section{Recommendations}

The study recommends that family members who are farmers should make efforts to put in place food processing and preservation techniques which will makes food available to the households all year round. Also governments in these states should support various extension agencies involved in the dissemination of these technologies that enhance the food security of the farmers.

\section{References}

Adeolu, B.A. \& Taiwo, A. (2004). The Impact of national fadama facility in alleviating rural poverty and enhancing agricultural development in south-western Nigeria. Journal of social science, 9(3): 157-161. pp 3-128.

Aneke, M. O. (2007). Impact of the phase-1 national special programme on food security on poverty reduction in Enugu state, Nigeria. An M Sc. Research findings presented to the Department of Agricultural Extension, University of Nigeria.

Attah. A.W. (2012). Food security in Nigeria: The role of peasant farmers in Nigeria. African research Review an An International Multidisciplinary Journal, Ethiopia Vol. 6 (4), Serial No. 27, October, 2012 http://dx.doi.org/10.4314/afrrev.v6i4.12

FAO, (1996).Socio-Political and Economic Environment for Food Security, Food and Agriculture Organization of the United Nations, World Food Summit, Vol. 1, Sec. 1.4

Ivande P.D. (2014). Assess to social and technological change in agriculture among the Tiv, in Nigeria, A Ph. D. Thesis submitted to the Department of Agricultural Extension, University of Nigeria.

Macionis, J.J. and Plummer, K. (2005). Sociology. A Global Introduction; Pearson Education Limited,Edinburgh Gate Hadow England. 
Creative Commons User Licence: CC BY-NC-ND

Abstracted by: EBSCOhost, Electronic Journals Service (EJS),

Google Scholar, Directory of Open Access Journals (DOAJ),

Journal Seek, Scientific Commons, and

Food and Agricultural Organization (FAO)
Journal of Agricultural Extension

Vol.19 (1) June, 2015

ISSN 24086851

http://journal.aesonnigeria.org

http://www.ajol.info/index.php/iae

Nana- Sinkam, S. (1995) Food, Self- sufficiency as a Strategic Option for Africa.In Onimode, B. and Synge, R. (EDS) Issues in African Development. Essays in honour of Adebayo Adedejoat 65. Heinemann Educational books (Nigeria) PLC and African Centre for Development and Strategic studies.

Obamiro, E. O., Doppler, W., and Kormawa, P.M. (2003). Pillars of food security in rural areas of Nigeria. food africa, internet forum $31^{\text {st }}$ March-1 $1^{\text {th }}$ April, 2003. Internet paper accepted for food security theme. http://foodafrica.nri.org/security/internetpaper/obamoiroeunice.pdf

Olaolu M.O., Akinnagbe O. M. and Agber, T (2013). Impact of national Fadama Development Project Phase (II) on poverty and food security among rice farming beneficiaries in Kogi State, Nigeria American Journal of Research Communication. Available on http://www.usa-journals.com/wp-content/uploads/2013/09/Olaolu_Vol110.pdf

Omonona,O., Bolarin, O. Agoi, A. and Adetokunbo, G. (2007) An Analysis of food security situation among Nigerian urban Households: evidence from Lagos state, Nigeria. Journal of Central European Agriculture Vol 8 No 3 pp 398-400

Oriola E.O. (2009) Aframework for Food security and poverty reduction in Nigeria, European Journal of Social Sceinces- Vol. 8, No1

Rivera, W.M. and Qamar, M.K. (2003). Agricultural Extension, Rural Development and the Food security challenge. FAO/ UN Rome

United States agency international development (USAID) (1992). Policy Paper entitled "Food aid and food security" (1992). http://www.usaid.gov

World Bank (1996). Nigeria: Poverty in the midst of plenty; the challenges of growth with inclusion. A world Bank poverty assessment, population and human resources division report; No. 14733-UNI, Washington, D.C., the World Bank.

World Bank. (2001). Strategy for Food and Nutrition Security. World Bank Report N0. 9040. Washington D.C. 